\title{
A Study of Coding Systems for the Wartegg Test and their Relations with the Rorschach (R-PAS)
}

\author{
Fernando Pessotto*, 1 \\ Orcid.org/0000-0002-4448-1577 \\ Ricardo Primi ${ }^{2}$ \\ Orcid.org/0000-0003-4227-6745
}

${ }^{1}$ Centro Universitário Salesiano São Paulo, Americana, SP, Brazil

${ }^{2}$ Universidade São Francisco, Itatiba, SP, Brazil

\begin{abstract}
The Wartegg Test is composed of eight squares with small graphical stimuli in which the person must elaborate drawings from them. Although existing for almost 80 years, it still features inconsistencies in terms of validity evidence and, therefore, its use in decision making. This research aimed to propose a new mode for coding and interpretation for the technique and was divided into two studies. In the first, five different systems were identified with the aim of verifying potential variables with greater discriminative power. In the second, six judges verified which Rorschach variables could be used in a similar way in the Wartegg Test. The new system proposed presents 13 groups of classification criteria, such as orientation, localization, size, content, quality of the objects, form quality, common response, particular characteristics, special codes, line pressure, line type, repetition, sequence analysis and title.
\end{abstract}

Keywords: Psychological evaluation, self-expression techniques, graphical techniques.

\section{Estudo de Sistemas de Codificação do Teste de Wartegg e suas Relações com o Rorschach (R-PAS)}

\section{Resumo}

O Teste de Wartegg é composto por 8 quadros contendo pequenos estímulos gráficos, tendo o sujeito que realizar um desenho a partir deles. Mesmo tendo quase 80 anos de existência, ainda apresenta inconsistências no que diz respeito às evidências de validade e consequente, uso para tomada de decisão. A presente pesquisa teve como objetivo propor um novo modo de codificação e interpretação para a técnica e foi dividida em dois estudos. No primeiro verificou-se cinco diferentes sistemas a fim de verificar potenciais variáveis com maior poder discriminativo. No segundo, seis juízes verificaram quais variáveis do Rorschach poderiam ser utilizadas de forma similar no Teste de Wartegg. Por fim o novo sistema proposto apresenta 13 grupos de critérios para classificação, à saber, orientação, localização, tamanho, conteúdo, qualidade dos objetos, qualidade formal, resposta popular, características particulares, códigos especiais, pressão do traço, tipo do traço, repetição, análise de sequência e título.

Palavras-chave: Avaliação psicológica, técnicas de autoexpressão, técnicas gráficas.

* Mailing address: Centro Universitário Salesiano São Paulo, Campus Americana, Av. de Cillo, 3500, Parque Universitário, Americana, SP, Brazil 13467-600. E-mail: fpessotto@gmail.com and rprimi@uol.com.br Support: Coordenação de Aperfeiçoamento de Pessoal de Nível Superior (CAPES). 


\section{Un Estudio de Codificación de la Prueba de Wartegg y sus Relaciones con el Rorschach (R-PAS)}

\section{Resumen}

La prueba de Wartegg es composta por ocho cuadros que contienen pequeños estímulos gráficos, en los cuales el sujeto tiene que elaborar dibujos. Aunque con casi 80 años de existencia, presenta inconsistencias al respecto de las evidencias de validad y, consecuente, uso en la toma de decisiones, todavía. La presente investigación objetivó proponer un nuevo modo de codificación y interpretación para la técnica y fue dividida en dos estudios. En el primero verifico-se cinco diferentes sistemas de corrección, a fim de verificar potenciales variables con mayor poder discriminativo. En el segundo, seis jueces verificaron cuales variables del Rorschach podrían ser utilizadas de forma similar en la prueba de Wartegg. Finalmente el nuevo sistema propuesto presenta 13 grupos de criterios para clasificación, a saber: orientación, localización, tamaño, contenido, cualidad de los objetos, cualidad formal, respuesta popular, características particulares, códigos especiales, presión del guión, tipo del guión, repetición, análisis de secuencia y titulo.

Palabras clave: Evaluación psicológica, técnicas de auto-expresión, técnicas gráficas.

Psychological evaluation is a scientifically based process that seeks to understand issues of the psychological functioning of individuals with the aim of guiding, suggesting and sustaining inferences made from this information (Noronha \& Alchieri, 2004). In this process, several techniques and tests are used to measure and explore psychological variables, among these those of self-expression, composed of unstructured stimuli, not linked to an a priori construct, in order to favor individual expression in the formulation of the response (Fensterseifer \& Werlang, 2008; Meyer \& Kurtz, 2006).

The self-expression techniques seek to generate understanding about the dynamics of the personality, accessing them from the perspective experienced or perceived by the subject. They presuppose, therefore, that the external requirement, characterized in the tests by marks, drawings and stories, among others, has a relation with the internal way in which the individuals organize their perceptions. Consequently, this is possibly important in other contexts besides the personality, characterizing the psychic functioning from a perspective different to the symptomatic classifications described in the disease classification manuals (Fensterseifer \& Werlang, 2008; VillemorAmaral \& Pasqualini-Casado, 2006).
According to Werlang and Cunha (1993), in the interaction with the stimulus, internal materials of the individual are revealed, indicating balance or not, with respect to the resources available in the regulation of conflicts. Because they are stimuli with little structure, they provide hardly any subsidies for the subject to use conventional information or responses. Anastasi and Urbina (2000) added that, because there is no correct or socially adequate response, the individual has little inhibition when responding and, consequently, the probability of manipulating the results is lower.

This comprehension of the person contrasts with the psychometric tradition that values quantitative data and, conversely, emphasizes qualitative information, seeking the identification of spontaneous tendencies, motivated by implicit needs. However, it should be noted that the two sources of information are equally important (Villemor-Amaral \& Pasqualini-Casado, 2006). Underlying all action is the individuality of the subject who exercises it and implies a particular way of perceiving it. Bellak named this processing apperception (Silva, 1989), defined as the process by which experience is subjectively perceived, assimilated and interpreted by the subject (Werlang, 2002). 
Silva (1989) explains that apperception is part of a continuum that ranges from a completely objective perception of reality to the extreme apperception that can imply the breakdown of contact with reality even assuming a pathological character, that is, an apperceptive deformation. Several perceptions occur simultaneously, seeking to contemplate as much of the available stimuli as possible, in an interactive process implying a gestalt principle in which the whole is more than the sum of the parts.

The Wartegg Test or Complement Drawing Test is one of the self-expression techniques, originally developed by the German psychologist Ehrig Wartegg and presented to the scientific community for the first time in 1937 in Germany under the name of the Wartegg Zeichentest - WZT (Freitas, 1993; Roivainen, 2009). It is an expressive, semi-structured graphical test that seeks to verify aspects of the personality, namely, emotion, imagination, intellect and activity (the latter found in the Brazilian literature as action or will). It consists of eight squares (Fields), each containing a printed stimulus, with the subject asked to continue the drawing by forming a picture in each frame. A point, a small wavy line, three ascending lines, a small black square, two opposing straight lines, two straight unarticulated lines, a small dotted semicircle and a large semicircle are arranged in Fields 1 to 8, respectively (Crisi, 2007; Freitas, 1993; Kinget, 1952).

Kinget (1952) highlighted that the theoretical framework of the Wartegg Test was based on so-called Ganzheit Psychologie (Holistic Psychology - literal translation). This theory conceives the subjects and their interactions with the tasks performed as structures to be analyzed. With regard to the subjects, their way of acting is composed of a set of characteristics of a dynamic nature that tend to organize the stimuli that are within the scope of the experience, with emotion being the main regulating element of this system. Thus, the experiences are marked by the individual structure and, consequently, it is possible to infer their characteristics. According to Biedma and D'Afonso (1973), the hypothesis proposed in the task of the Wartegg Test is that when performing the task, the individual does it according to his/her individual way of perceiv- ing, feeling, associating and acting, thus revealing the dynamics of his/her psychic structure.

Ehrig Wartegg, according to Kinget (1952), would have used the technique created by Sander, the Phantasie Test, as his basis, which seeks to empirically verify Ganzheit Psychologie. The stimuli that make up the test are irregular lines that have to be organized by the subject in some way. The productions performed favor the verification of marked differences in the structural features of each subject. In addition, Crisi (2007) and Freitas (1993) reported that the test is based on Gestalt Theory, considering that each individual has to present, when presented with the stimuli, a personal way of perceiving, feeling, associating and acting, allowing access to some characteristics of his/her psychic structure. According to this theory the properties of the parts depend on their relation to the whole, that is, their qualities depend on the place, role and function they have in relation to the whole.

The Wartegg Test has been well accepted and, as far as its use is concerned, Silva (2008) highlights that it presents some advantages, such as its rapid application, evaluation and interpretation, as well as the fact that the stimuli are considered neutral and unstructured, favoring acceptance by the majority of subjects. The author also says that a graphical production can favor free verbal communication, increasing the possibility of the analysis.

Even with these considerations, Roivainen (2009) reported that the Wartegg Test is practically unknown in Anglo-Saxon countries, however, its use is frequent in Latin America, Finland, Italy and Germany. In Brazil, it has been widely used in the organizational context, gaining prominence in the selection, evaluation and monitoring of professionals, as emphasized by Berlinck (2000). Alves, Alchieri, and Marques (2001) found that the Wartegg Test was in $5^{\text {th }}$ place among the self-expression tests most taught in undergraduate courses and in the study by Noronha, Beraldo and Oliveira (2003) the test was the $5^{\text {th }}$ most used by psychologists, being, therefore, an instrument of great importance in the Brazilian context. Even with this scenario, in 2005, the Wartegg Test received an unfavorable evaluation by the Federal Council of Psychology 
(CFP) for its use, due to not presenting studies, especially regarding evidence of validity and accuracy, according to the guidelines established by the CFP in Resolution 002/2003.

\section{Wartegg Test Coding Systems}

Ehrig Wartegg (1987) presented his first system, referred to as layered diagnostics, indicating the different classifications made from each of the frames. In this system the classification is carried out from the form quality, content, sequence and cognitive structure. With the exception of the sequence, in which the order of production of the drawings is analyzed, the others present subdivisions from aspects of the drawing.

The author emphasizes the importance of the evolutionary character in the execution, that is, of the analysis linked to the sequence of the drawings, exemplifying particularities of psychiatric diagnosis, learning difficulties, selective processes and vocational guidance, characterizing a typology for each subject involving emotion, imagination, intellect and energy (action). These considerations are largely based on purely clinical interpretations, founded in qualitative analyses, without always presenting solid justifications for the interpretation, however, the importance in the elaboration of the method, as well as the indications for which it is proposed, cannot be denied.

The second system was presented by Kinget $(1952,1991)$ who, in addition to the studies of Ehrig Wartegg, sought to conceptualize the typologies proposed by the author, introducing a complementary procedure in order to enable the investigation of verbal contents associated with the drawings produced. In his studies he devoted particular importance to the structure, to the protocol of responses and to their constituent elements. For the classification of the drawings used as groups of criteria, content, line, composition, details, organization, repetition, duplication, recurrence, variability, closure, orientation, care, relaxation/disinterest, movement, originality, common response, clear/vague and consistency/inconsistency.
In addition, the researcher systematized four basic functions evaluated by the Wartegg Test, namely, emotion (expansive and withdrawn), imagination (combinatorial and creative), intellect (practical and speculative) and activity (dynamic and controlling). The classification of the personality profile is performed from the combination of the aspects previously presented, with different intensities also being weighted for each of them, on a scale of five points. The study of these functions allows the behavioral styles that determine the typological classification to be identified as Vital-Emotional, Rational-Volitive and Integrated. Although having carried out quantitative analyses, the author emphasized the importance of qualitative analysis and used the results directed more toward the practice than toward theoretical requirements (Kinget, 1952).

Another system was proposed by Biedma and D'Afonso (1973) in which the authors made changes in the form of correction and even in the quantity of stimuli, going from 8 to 16 frames. According to this proposal, 3 aspects are analyzed, namely, behavior, situations and positioning. The authors also emphasized the importance of the values of the stimuli, highlighting the advantage of using pre-established stimuli because they already have archetypal characteristics.

In this proposal the authors presented a system of codification and consequent interpretation based on 3 elements, namely, factors of expression, integration and representation. Expression factors fundamentally indicate the subject's way of being, in which the choice of certain expressive modalities indicates the subject's type of functioning. This category is evaluated by characteristics such as clarity, dimension, dynamism, location, thickness, originality, pressure and simplicity. The integration factors concern the archetypal representations of the stimuli, taking into consideration the drawing made from it and its location in the frame, and are understood as simple or compound archetypes. Finally, the representation factors are related to the actual content of the drawings, in which the authors present a list with more than 80 possibilities, among them animals, trees, letters, food, fire, 
eyes, soldiers and tunnels, with indications of interpretations for each one (Biedma \& D'Afonso, 1973).

In Brazil, Freitas (1993) proposed the fourth system based on the work of Kinget (1952), which supports the idea that the technique makes it possible to analyze the personality structure with respect to basic functions, such as emotion, imagination, dynamism and control. For the interpretation of the results the author presented two forms, the projective approach and the expressive approach.

In the projective approach, the relationship between the gestalt/archetypal characteristic and the material produced by the subject is analyzed, investigating whether it is relevant or not. These characteristics are evidenced from the previous meanings of the stimuli described for each field. The classification of these occurs as motor, aesthetic or symbolic doodles, symmetrical decorative abstractions, asymmetrical decorative abstractions, or techniques and paintings or pictures that receive the classifications realism (animate nature, physiognomy, schematism and inanimate nature), objects, fantasies (fantasized reality, fairy stories, mythological figures, free fantasies, ghosts) and the repetition of the stimulus (Freitas, 1993).

In turn, the expressive approach considers the variables with reference to the properties of the drawings themselves. They are divided into graphical aspects (good, medium or low level of form), pencil pressure (very strong, strong, soft, very soft, irregular, variation in pressure), line (straight, curved, continuous, discontinuous, tremulous, reinforced, advances and retreats, and shading), size and graphical expansion, this being classifiedas small, large or compact(Freitas, 1993)

More recently, Crisi (2007) presented a new method of coding and interpretation for the Wartegg Test, justifying that the original, in addition to presenting unfavorable indices of validity evidence, presented a very complex and imprecise scoring method. Furthermore, the theoretical basis did not support all the evaluative complexity proposed by Ehrig Wartegg, making its use in clinical practice, for example, limited. Crisi proposed a system of coding, scoring and interpretation based on the Rorschach in the Roman School for which, in addition to providing a more objective character, allows the comparison between the two tests.

Thus, nine categories were proposed for the coding of the results, namely, evocative character, affective quality, form quality, content, frequency, particular phenomena, movement, impulse response and order of succession or execution. The author highlighted that, with the exception of the evocative character, affective quality and order of succession, all the others were established from the variables of the Rorschach. In addition to these variables, the author proposed a clinical analysis based on the archetypal meanings of the stimuli based on thematic interpretations related to the Rorschach boards (Crisi, 1998, 2007). Recently Crisi and Dentale (2016) investigated the categories of evocative character, form quality and affective quality more deeply, finding significant differences in these variables among anxious, psychotic and non-psychiatric groups.

Despite this system having well defined psychometric characteristics, no studies of validity evidence for the technique, its theoretical basis and theoretical validity were found. However, it has been shown to be an important systematization in the search for a reliable coding and interpretation system for the Wartegg Test. Souza, Primi, and Miguel (2007) highlighted that, although many interpretations based on the results of the Wartegg Test do not have empirical support, some variables seem to be associated with personality traits and, therefore, they suggest new studies that make their verification and comprehension possible.

Gronnerod and Gronnerod (2012) also stated that interpretations made from the results of the Wartegg Test can reach levels comparable with other evaluation methods. Furthermore, the authors pointed out that there is no reason to reject it as a personality assessment method, however, it is necessary to construct a solid system, with studies generating accumulated knowledge for its use. They also indicated the need for new research based on the existing studies in order to strengthen the method used. 
This type of systematization was employed by Exner for the Comprehensive System (CS) of the Rorschach test. This systematization gave the Rorschach-CS the necessary psychometric rigor, with a good degree of concordance between judges in their codification and interpretation, good reliability and error variance and normative data (Costantino, Flanagan, \& Malgady, 1995; Exner, 1999; Weiner, 2000).

More recently, Meyer, Viglione, Mihura, Erard, and Erdberg (2011), proposed the Rorschach Performance Assessment System (R-PAS), a coding and interpretation system based on the Comprehensive System directed toward the improvement in the use of some variables due to the large variation in the number of responses. In addition, the new method sought to simplify the process of applying the technique by limiting the number of responses from 2 to 3 per board, with new groupings of variables based on psychometric evidence, thus seeking greater assertiveness in the interpretations made from the results.

Meyer et al. (2011) emphasized that the new system can be considered an international and updated approach to the technique as a consequence of scientific advances related to the assessment of the personality. Viglione, Meyer, Mihura, Erard, and Erdberg (2012) added that this update also aims to simplify the learning of the technique by psychologists. In this sense, the main variables maintained the same codes as the Comprehensive System, while others were adapted for the improvement of the system.

In this sense, the present study aimed to investigate different coding systems for the Wartegg Test and to identify similarities among them that could compose a new coding system. To achieve this objective the research was divided into two studies. The first one aimed to verify which coding variables are the same among five coding systems for the Wartegg Test, namely those of Biedma and D'Afonso (1973), Crisi (2007), Freitas (1993), Kinget (1952) and Wartegg (1987), and which are more discriminatory. The second study aimed to verify which variables of the system employed by the Rorschach RPAS can be used as criteria for the Wartegg Test.

\section{Study 1}

\section{Method}

Materials. The Wartegg test application, correction and interpretation manuals of Biedma and D'Afonso (1973), Crisi (2007), Freitas (1993), Kinget (1952), and Wartegg (1987), and were used as the consultation sources.

Procedures. Each of the manuals was studied with particular emphasis on the coding systems, that is, the attribution of classifications from the description of the criteria for classification of the attributes of the drawings. Subsequently, the classifications and possible sub-classifications for the drawings in each of the systems were organized in a spreadsheet.

\section{Results and Discussion}

In order to verify the similarities between the systems, the possible classifications for the drawings were organized in a spreadsheet according to the systems that contained them (Table 1). This analysis was based on the application of the criteria for the attributes of the drawings. The meanings attributed to each indicator in the systems were often different or only had meanings assigned when grouped with others, therefore it was decided to focus on the classification criteria, since the meanings of these indicators will be the object of future studies. Thus, these data summarize the categories found in the five systems, indicating the replications and those that are specific to some systems.

It can be seen that only one of the classifications, the content, is used in all five systems studied. The criteria for this score refer to the elements present in the drawing created, indicating, in general, the focus of attention expressed in the execution of the task. It is also possible to consider that, because it is a graphical test, the contents are considered projective elements of great significance for the analysis of the evaluee (Silva, 1989).

The form quality, which refers to the relationship between the object and the stimulus previously presented in the table, and the size are used in four of the systems studied, with the attributes of the quality of the drawing also 
Table 1

Classifications Present in the Coding Systems of the Wartegg Test

\begin{tabular}{|c|c|c|c|c|c|c|c|c|c|c|c|c|c|}
\hline Systems & 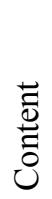 & 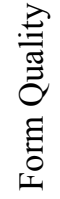 & $\stackrel{\tilde{N}}{\sim}$ & 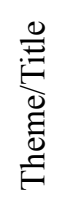 & 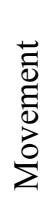 & 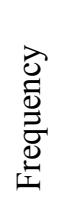 & $\begin{array}{l}\ddot{U} \\
\bar{\Xi} \\
\vec{J} \\
\tilde{J}\end{array}$ & $\stackrel{\mathscr{\Xi}}{.}$ & 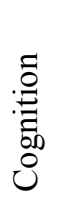 & 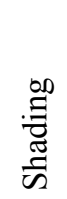 & 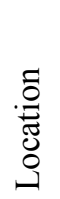 & 苟 & $\begin{array}{l}\frac{n}{\pi} \\
\text { D. } \\
0\end{array}$ \\
\hline Wartegg (1987) & $\mathrm{X}$ & $\mathrm{X}$ & & & & & X & & $X$ & & & & \\
\hline Kinget (1952) & $\mathrm{X}$ & & $\mathrm{X}$ & $\mathrm{X}$ & $\mathrm{X}$ & $\mathrm{X}$ & & $\mathrm{X}$ & $\mathrm{X}$ & $\mathrm{X}$ & & & $\mathrm{X}$ \\
\hline Biedma \& D’Afonso (1973) & $X$ & $X$ & $X$ & $X$ & & $\mathrm{X}$ & & $\mathrm{X}$ & & & $X$ & & \\
\hline Freitas (1993) & $\mathrm{X}$ & $\mathrm{X}$ & $\mathrm{X}$ & $\mathrm{X}$ & X & & X & $\mathrm{X}$ & & $\mathrm{X}$ & & $\mathrm{X}$ & \\
\hline Crisi (2007) & X & $X$ & $X$ & $X$ & $X$ & $X$ & $X$ & & & & & & \\
\hline
\end{tabular}

highlighted due to their importance, although the criteria differ in the systems. For Biedma and D'Afonso (1973), Crisi (2007) and Freitas (1993), form quality refers to the relationship between the design and the initial stimulus, while for Wartegg (1987), in addition to the use of the stimulus, characteristics such as the overlapping of the frame and the reinforcement of the initial signal are considered. In turn, size refers to the space within the frame used by the subject.

The theme or title was also verified in four of the five systems, not only used by Wartegg (1987). For the other authors, this criterion was used mainly as qualitative data, complementing other indicators of the coding.

Next, movement, frequency, sequence and line are present in three systems. Movement is presented in various ways, sometimes as a subclassification and at other times as the main code. Kinget (1952) presents movement as the main code divided into without movement, cosmic movement, mechanical movement, and active human movement. In the system of Freitas (1993) movement is attributed in the dynamic code which in turn is a sub-classification of the type of line. Finally, Crisi (2007) includes classifications for movement within the main code of content. This classification is due to primary and secondary movements involving sub-classifications such as sex, male, female, undefined, animal, inanimate object and physiognomic expressions, with it being necessary to indicate their direction in extensive, flexive, blocked, double, rotational and indeterminate divisions.
For the three systems, frequency is based on studies that have observed the drawings created with more or less frequency, being also connected to the originality classification, proposed by Biedma and D'Afonso (1973) and Kinget (1952). For the analysis of the sequence, although the five systems propose observing the development of the subject throughout the test, this only composes a classification criterion in three, providing classifications for different types of order of execution. Regarding the line, the systems classify it regarding the pressure/intensity and also the type of line used.

It can be observed that cognition and shadowing are used in two systems. Cognition refers to the cognitive structure and, although cited by other systems, only Kinget (1952) and Wartegg (1987) present indicators related to cognitive organization, being basically related to the complexity and structure involved in the creation of the drawings, such as the inclusion or absence of details, three-dimensional designs, among others. With regard to shading, both Freitas (1993) and Kinget (1952) use the presence of this element in the drawing.

Finally, location is used by Biedma and D'Afonso (1973) to indicate the area used by the subject in the creation of the drawing, with vertical and horizontal orientations being considered. Regarding affection, Crisi (2007) presents a classification used for the affective quality presented in the drawing or even expressed verbally.

Although the criteria for applying the codes cited above have been studied, the detailed pre- 
sentation of each one is beyond the scope of this study. What stands out is the character, often purely idiographic, for the attribution of the criteria. This clinical information is important and composes part of the evaluation process, however, Villemor-Amaral (2006, 2009) emphasizes the need to extend validity evidence for the selfexpression techniques by creating systems that favor greater agreement between the evaluators through means of objective criteria.

Villemor-Amaral and Pasqualini-Casado (2006) verified that there are few studies of these techniques, based on psychometric parameters. Some techniques, because they have a great clinical tradition, are used in these types of studies, as is the case of the Rorschach Comprehensive System (Rorschach-SC). Others, such as Human Figure Drawing (DFH), Thematic Apperception Test (TAT), Infant Apperception Test (CAT) and the Wartegg Test are encountered less frequently in the specialized literature, which is one of the difficulties found with regard to reliable systems of evaluation and interpretation.

Lilienfeld et al. (2000) already indicated that, for some self-expression techniques, the criteria used for the correction and consequent interpretation are often based only on a clinical judgment, underestimating the technical and methodological rigor of psychometric procedures, which makes the generalizations of the interpretations unfeasible. Villemor-Amaral (2008) adds that the interpretation made from self-expression techniques should use clear structural parameters derived from theories. In agreement, few studies with the Wartegg Test were found and some presented unfavorable evidence for its use (Roivainen, 2009; Silva, 2008; Souza et al., 2007).

In this sense, classifications were proposed that favored the application in a clear way, that is, those in which the classification criteria were sufficiently clear in the coding. As this is an exploratory study for the creation of a new system, it was considered important to maintain all possible criteria to be used in the coding of the drawings. Eventually, future studies will indicate those with better accuracy or even those that do not have discriminatory strength for the latent traits of the individuals.

The final system was composed of 13 criteria, some containing sub-classifications. The primary classifications proposed were orientation, location, size, content, quality of the objects, form quality, common response, particular characteristics, special codes, line, repetition, sequence analysis and title. With the exception of sequence analysis, each classification should be assigned to the 8 frames, some of which may contain more than one code.

\section{Study 2}

\section{Method}

Participants. Six judges, 4 doctors and 2 doctoral candidates, with experience in selfexpression techniques participated in this study. The ages of the judges varied between 32 and 41 years $(M=36.83 ; S D=3.31)$, with four of the judges being male. In relation to their locations, four worked in the state of São Paulo, one in Pará and the other in Minas Gerais.

\section{Materials}

Table of the variables of the Wartegg Test and Rorschach Method. Two spreadsheets were developed for this study. Spreadsheet 1 contained the 10 groups of Rorschach indicators (R-PAS), namely orientation, location, spaces, content, quality of the objects, form quality, common response, determinants, cognitive codes and thematic codes. When clicking on each of them, another page opens containing the indicator and its criteria in the Rorschach (R-PAS). The judges had to indicate how each of the criteria could be used in the Wartegg Test. For example, based on the R-PAS definition of form quality (FQ), the judges should state how this criterion could be used considering the task of the Wartegg Test.

Spreadsheet 2 contained the same indicators, however, those of the Rorschach (R-PAS) were presented and the judge had to indicate which would correspond in the Wartegg Test (in this sheet the relationship was already indicated 
by the authors of this study), with the possibility of justifying the response. That is, the judges had to verify the theoretical relevance between the variables indicated, i.e. whether an indicator used in the R-PAS can be used in the same way for the Wartegg Test, providing a theoretical justification for the response. The judges were also able to indicate whether an indicator of the RPAS could be used in another coding criterion in the Wartegg Test. In both cases, a brief explanation of the task to be carried out in the Wartegg Test, a blank stimuli sheet and a completed example, in order to resolve any doubts, and a questionnaire contemplating socioeconomic and training aspects, such as highest qualification and practical use of self-expression techniques, were included.

Procedures. With the work approved by the Research Ethics Committee of the University of São Francisco, the judges were invited to participate in the study and, after electronic signing of the consent form, received the study material via email. A total of 17 judges were invited, of whom eight would respond to Worksheet 1 and nine to Worksheet 2. In the end, six judges agreed to participate in the study, four of whom responded to Worksheet 1 and two to Worksheet 2 .

Data analysis plan. The answers of the judges were analyzed qualitatively considering the similarities indicated by them, as well as the considerations listed. In this sense, the agreement between them was verified with respect to which criteria could be used in the Wartegg Test, with an analysis of the content of the justifications that were presented.

\section{Results and Discussion}

In order to verify the potentially common variables between the Wartegg test and the Rorschach test (R-PAS), the judges indicated, based on their experiences with self-expression techniques, more specifically with the Rorschach, those that could fit the proposal. Table 2 presents the relationships indicated.

Of the 68 codes, divided into 10 analyzed groups, 27 were considered common to the instruments by all judges, 20 by 5 judges and 10 by
4 of the judges. These variables were considered relevant for the new system under development for the Wartegg Test, considering their relevance in the Rorschach (R-PAS) system. The others (i.e., 11 codes that were considered relevant by 3 judges or fewer) were not included in the new system. In addition to the indications presented in Table 2, the comments made by the judges related to several variables were also considered.

Verifying the similarity between the systems can favor the creation of a new system for the Wartegg Test based on an instrument already widely used and researched, such as the Rorschach, as indicated by Gronnerod and Gronnerod (2012). In addition, it can facilitate studies between the instruments as evidence of validity and consequential validity conferring a better degree of agreement between the judges for the Wartegg Test, in the interpretation and reliability, as verified by Costantino et al. (1995), Exner (1999) and Weiner (2000) for the Rorschach.

After this analysis and the considerations of study 1, 13 criteria of classification were evidenced for the Wartegg test, that is, in the systems studied, 14 criteria were found for use in the coding of the instrument. The criteria proposed were orientation, location, size, content, quality of the objects, form quality, common response, particular characteristics, special codes, line (line pressure and type), repetition, analysis of the sequence and title.

\section{Final Considerations}

The Study 1 was carried out in order to study five coding systems of the Wartegg Test, namely, Biedma and D'Afonso (1973), Crisi (2007), Freitas (1993), Kinget (1952), and Wartegg (1987), aiming to verify their classification criteria for the drawings created, with the verification of 13 sets of variables used. Study 2, sought to verify which Rorschach (R-PAS) variables could be used for the Wartegg Test, based on their tasks. Some variables in common were verified, as well as others used only by one of the systems, as described in the results.

Even with several systems, the instrument still presents few psychometric studies, which 
Table 2

Variables with Similarity between the Wartegg Test and the Rorschach (R-PAS) Indicated by the Judges

\begin{tabular}{|c|c|c|c|c|c|c|c|c|}
\hline Classification & code & Judge 1 & Judge 2 & Judge 3 & Judge 4 & Judge 5 & Judge 6 & TOTAL \\
\hline \multirow[t]{4}{*}{ Orientation } & $<$ & 1 & 0 & 1 & 1 & 1 & 1 & 5 \\
\hline & $>$ & 1 & 0 & 1 & 1 & 1 & 1 & 5 \\
\hline & $\mathrm{v}$ & 1 & 0 & 1 & 1 & 1 & 1 & 5 \\
\hline & (a) & 1 & 0 & 1 & 1 & 0 & 1 & 4 \\
\hline \multirow[t]{3}{*}{ Location } & W & 1 & 1 & 1 & 1 & 1 & 1 & 6 \\
\hline & $\mathrm{D}$ & 1 & 1 & 1 & 1 & 1 & 1 & 6 \\
\hline & $\mathrm{Dd}$ & 0 & 0 & 1 & 1 & 1 & 1 & 4 \\
\hline \multirow[t]{2}{*}{ Spaces } & SR & 0 & 0 & 1 & 1 & 0 & 1 & 3 \\
\hline & SI & 1 & 0 & 1 & 0 & 0 & 1 & 3 \\
\hline \multirow[t]{17}{*}{ Content } & $\mathrm{H}$ & 1 & 1 & 1 & 1 & 1 & 1 & 6 \\
\hline & $(\mathrm{H})$ & 1 & 1 & 1 & 1 & 1 & 1 & 6 \\
\hline & $\mathrm{Hd}$ & 1 & 1 & 1 & 1 & 1 & 1 & 6 \\
\hline & (Hd) & 1 & 0 & 1 & 1 & 1 & 1 & 5 \\
\hline & $\mathrm{A}$ & 1 & 0 & 1 & 1 & 1 & 1 & 5 \\
\hline & (A) & 1 & 0 & 1 & 1 & 1 & 1 & 5 \\
\hline & Ad & 1 & 0 & 1 & 1 & 1 & 1 & 5 \\
\hline & $(\mathrm{Ad})$ & 1 & 0 & 1 & 1 & 1 & 1 & 5 \\
\hline & An & 1 & 1 & 1 & 1 & 1 & 1 & 6 \\
\hline & Art & 1 & 1 & 1 & 1 & 1 & 1 & 6 \\
\hline & Ay & 1 & 1 & 1 & 1 & 1 & 1 & 6 \\
\hline & $\mathrm{Bl}$ & 1 & 0 & 1 & 1 & 1 & 1 & 5 \\
\hline & $\mathrm{Cg}$ & 1 & 1 & 1 & 1 & 1 & 1 & 6 \\
\hline & Ex & 1 & 1 & 1 & 1 & 1 & 1 & 6 \\
\hline & $\mathrm{Fi}$ & 1 & 1 & 1 & 1 & 1 & 1 & 6 \\
\hline & $\mathrm{Sx}$ & 1 & 1 & 1 & 1 & 1 & 1 & 6 \\
\hline & $\mathrm{NC}$ & 1 & 1 & 1 & 1 & 1 & 1 & 6 \\
\hline \multirow[t]{3}{*}{ Quality of the Objects } & Sy & 1 & 1 & 1 & 1 & 1 & 1 & 6 \\
\hline & $\mathrm{Vg}$ & 1 & 1 & 1 & 1 & 1 & 1 & 6 \\
\hline & Par (2) & 0 & 0 & 0 & 0 & 0 & 1 & 1 \\
\hline \multirow[t]{4}{*}{ Form Quality } & o & 1 & 1 & 1 & 1 & 1 & 1 & 6 \\
\hline & $\mathrm{u}$ & 1 & 1 & 1 & 1 & 1 & 1 & 6 \\
\hline & - & 1 & 1 & 1 & 1 & 1 & 1 & 6 \\
\hline & $\mathrm{n}$ & 1 & 0 & 0 & 1 & 1 & 1 & 4 \\
\hline
\end{tabular}




\begin{tabular}{|c|c|c|c|c|c|c|c|c|}
\hline Common Response & $\mathrm{P}$ & 1 & 1 & 1 & 1 & 1 & 1 & 6 \\
\hline \multirow[t]{15}{*}{ Determinants } & M & 1 & 1 & 1 & 1 & 1 & 1 & 6 \\
\hline & FM & 1 & 1 & 1 & 1 & 1 & 1 & 6 \\
\hline & $\mathrm{m}$ & 1 & 1 & 1 & 1 & 1 & 1 & 6 \\
\hline & $\mathrm{a}$ & 1 & 1 & 1 & 0 & 1 & 1 & 5 \\
\hline & $\mathrm{p}$ & 1 & 1 & 1 & 0 & 1 & 1 & 5 \\
\hline & $\mathrm{FC}$ & 0 & 0 & 0 & 0 & 0 & 0 & 0 \\
\hline & $\mathrm{CF}$ & 0 & 0 & 0 & 0 & 0 & 0 & 0 \\
\hline & $\mathrm{C}$ & 0 & 0 & 0 & 0 & 0 & 0 & 0 \\
\hline & $\mathrm{C}^{\prime}$ & 1 & 0 & 0 & 0 & 1 & 0 & 2 \\
\hline & $\mathrm{T}$ & 0 & 0 & 1 & 0 & 1 & 1 & 3 \\
\hline & $\mathrm{V}$ & 0 & 1 & 1 & 1 & 1 & 0 & 4 \\
\hline & $\mathrm{Y}$ & 0 & 1 & 1 & 1 & 1 & 0 & 4 \\
\hline & FD & 1 & 1 & 1 & 0 & 1 & 1 & 5 \\
\hline & $\mathrm{r}$ & 0 & 0 & 0 & 0 & 1 & 0 & 1 \\
\hline & $\mathrm{F}$ & 1 & 0 & 1 & 1 & 1 & 0 & 4 \\
\hline \multirow[t]{8}{*}{ Cognitive Codes } & Level I & 0 & 1 & 1 & 0 & 0 & 1 & 3 \\
\hline & Level II & 0 & 1 & 0 & 0 & 0 & 1 & 2 \\
\hline & DV (I e II) & 1 & 0 & 1 & 0 & 1 & 1 & 4 \\
\hline & DR (I e II) & 1 & 0 & 1 & 0 & 1 & 1 & 4 \\
\hline & PEC & 1 & 0 & 1 & 0 & 1 & 1 & 4 \\
\hline & INC (I e II) & 1 & 1 & 1 & 0 & 1 & 1 & 5 \\
\hline & FAB (I e II) & 1 & 1 & 1 & 1 & 1 & 1 & 6 \\
\hline & $\mathrm{CON}$ & 1 & 1 & 1 & 1 & 1 & 1 & 6 \\
\hline \multirow[t]{11}{*}{ Thematic Codes } & ABS & 1 & 1 & 1 & 0 & 1 & 1 & 5 \\
\hline & PER & 1 & 1 & 1 & 0 & 1 & 1 & 5 \\
\hline & $\mathrm{COP}$ & 1 & 1 & 1 & 0 & 1 & 1 & 5 \\
\hline & MOR & 1 & 1 & 1 & 0 & 1 & 1 & 5 \\
\hline & MAH & 1 & 0 & 1 & 0 & 1 & 1 & 4 \\
\hline & MAP & 1 & 1 & 1 & 0 & 1 & 1 & 5 \\
\hline & GHR & 1 & 1 & 1 & 1 & 1 & 1 & 6 \\
\hline & PHR & 1 & 1 & 1 & 1 & 1 & 1 & 6 \\
\hline & $\mathrm{AGM}$ & 1 & 1 & 1 & 0 & 1 & 1 & 5 \\
\hline & $\mathrm{AGC}$ & 1 & 1 & 1 & 1 & 1 & 1 & 6 \\
\hline & ODL & 1 & 1 & 1 & 0 & 1 & 1 & 5 \\
\hline
\end{tabular}


makes it difficult to verify similarities in the different systems in greater detail. However, most of the criteria studied present almost exclusively idiographic content, which makes it difficult for different judges to produce coding and subsequent interpretations that are similar. The system proposed is the beginning of a restructuring of the instrument and should be investigated in future studies, taking into account evidence of validity and reliability, seeking a better comprehension of the latent skills intrinsic to the indicators of the technique.

In this sense, the present study allowed the identification of a set of criteria to be used in the coding of the drawings created in the Wartegg Test. The final composition presents 13 sets of criteria with sub-criteria, these being, orientation, location (vertical, horizontal, central and total), size (small, large or medium), content (whole human figure, whole parahuman figure, part of human figure, part of parahuman figure, whole animal, whole paraanimal, part of animal, part of paraanimal, anatomy, art, anthropology, blood, clothing, explosion, fire, sex, other) quality of the objects (synthesis or vague) form quality (ordinary, unusual, distorted), common response, particular characteristics (human movement, animal movement, inanimate movement, depth [shading], texture, depth [not relative to shading]), special codes (fuzzy combination, contamination, abstract representation, personalized response, cooperative movement, morbid, mutuality of healthy autonomy, mutuality of pathological autonomy, good human representation, poor human representation, aggressive movement, aggressive content and dependent language), line - pressure (light, moderate, heavy) line - type (continuous, discontinuous, tremulous, or reinforced), repetition, analysis of the sequence, and title.

\section{References}

Alves, I. C. B., Alchieri, J. C., \& Marques, K. (2001). Panorama geral do ensino das técnicas de exame psicológico no Brasil (pp. 10-11). Paper presented at the I Congresso de Psicologia Clínica - Programas e Resumos. São Paulo, SP: Universidade Presbiteriana Mackenzie.
Anastasi, A., \& Urbina, S. (2000). Testagem psicológica. Porto Alegre, RS: ArtMed.

Berlinck, V. (2000). O teste de completamento de desenos Wartegg em universitarios de São Paulo (Master thesis). Universidade de São Paulo, SP, Brazil.

Biedma, C. J., \& D'Afonso, P. G. (1973). A linguagem do desenho - Teste de Wartegg - Bidema. São Paulo, SP: Mestre Jou.

Costantino, G., Flanagan, R., \& Malgady, R. (1995). The history of the Rorschach: Overcoming bias in multicultural projective assessment. Rorschachiana, 20(1), 148-171. doi: http://doi. org/10.1027/1192-5604.20.1.148

Crisi, A. (1998). Introducción al Test de Completamiento de Dibujo Wartegg (W.D.C.T.). Buenos Aires: Asociación Argentina de Estudio e Investigación en Psicodiagnóstico.

Crisi, A. (2007). Manuale del test di Wartegg. Norme per la raccolta, la siglatura e l'interpretazione (2. ed.). Roma: Magi Edizione.

Crisi, A., \& Dentale, F. (2016). The Wartegg Drawing Completion Test: Inter-rater Agreement and Criterion Validity of Three New Scoring Categories. International Journal of Psychology and Psychological Therapy, 16(1), 83-90.

Exner, J. E. (1999). Manual de interpretação do Rorschach para o sistema compreensivo. São Paulo, SP: Casa do Psicólogo.

Fensterseifer, L., \& Werlang, B. S. G. (2008). Apontamentos sobre o status científico das técnicas projetivas. In A. E. de Villemor-Amaral \& B. S. G. Werlang (Eds.), Atualizações em Métodos Projetivos para Avaliação Psicológica (pp. 1533). São Paulo, SP: Casa do Psicólogo.

Freitas, A. M. L. (1993). Guia de Aplicação e Avaliação do Teste Wartegg. São Paulo, SP: Casa do Psicólogo.

Gronnerod, J. S., \& Gronnerod, C. (2012). The Wartegg Zeichen Test: A literature overview and a meta-analysis of reliability and validity. Psychological Assessment, 24(2), 476-489. doi: http:// doi.org/10.1037/a0026100

Kinget, G. M. (1952). The drawing-completion test: A projective technique for the investigation of personality, based on the Wartegg test blank. New York: Grune \& Stratton.

Kinget, G. M. (1991). O teste de Completamento de Figuras. In E. F. Hammer (Ed.), Aplicações 
Clínicas dos Desenhos Projetivos. São Paulo, SP: Casa do Psicólogo.

Lilienfeld, S. O., Wood, J. M., \& Garb, H. N. (2000). The Scientific Status of Projective Techniques. Psychological Science in the Public Interest, 1(2), 27-66. doi: http://doi.org/10.1111/15291006.002

Meyer, G. J., \& Kurtz, J. E. (2006). Advancing personality assessment terminology: Time to retire "objective" and "projective" as personality test descriptors. Journal of Personality Assessment, 87(3), 223-225. doi: http://doi.org/10.1207/ s15327752jpa8703_01

Meyer, G. J., Viglione, D. J., Mihura, J. L., Erard, R. E., \& Erdberg. (2011). Rorschach Performance Assessment System. Toledo, OH: Rorschach Performance Assessment System.

Noronha, A. P. P., \& Alchieri, J. C. (2004). Knowledge in psychological assessment. Estudos de Psicologia (Campinas), 21(1), 43-52. doi: http:// doi.org/10.1590/S0103-166X2004000100004

Noronha, A. P. P., Beraldo, F. N. de M., \& Oliveira, K. L. de. (2003). Well-know psychological instruments used by psychology students and professional. Psicologia Escolar e Educacional, 7(1), 47-56. doi: http://doi.org/10.1590/S141385572003000100005

Roivainen, E. (2009). A Brief History of the Wartegg Drawing Test. Gestalt Theory, 31(1), 55-71.

Silva, M. C. de V. (1989). TAT: Aplicação e interpretação do Teste de Apercepção Temática. São Paulo, SP: EPU.

Silva, M. C. de V. (2008). O teste de completamento de desenhos de Wartegg (WZT). In A. Elisa \& B. S. G. Werlang (Eds.), Atualizações em métodos projetivos para avaliação psicológica. São Paulo, SP: Casa do Psicólogo.

Souza, C. V. R. de, Primi, R., \& Miguel, F. K. (2007). Validade do Teste Wartegg: Correlação com 16PF, BPR-5 e desempenho profissional. Avaliação Psicológica, 6(1), 39-49.

Viglione, D. J., Meyer, G. J., Mihura, J. L., Erard, L., \& Erdberg, P. (2012). The Rorschach
Performance Assessment System and advances in the Rorschach method. Paper presented at the VI Congresso da Associação Brasileira de Rorschach e Métodos Projetivos. Métodos projetivos e avaliação psicológica: Atualizações, avanços e perspectivas, Brasília, DF.

Villemor-Amaral, A. E. de. (2006). Desafios para a cientificidade das técnicas projetivas. In A. P. P. Noronha, A. A. A. dos Santos, \& F. F. Sisto (Eds.), Facetas do fazer em avaliação psicológica (pp. 163-171). São Paulo, SP: Vetor.

Villemor-Amaral, A. E. de. (2008). A validade teórica em avaliação psicológica. Psicologia: Ciência e Profissão, 28(1), 98-109. doi: http://doi. org/10.1590/S1414-98932008000100008

Villemor-Amaral, A. E. de. (2009). Métodos Projetos em Avaliações Compulsórias: Indicadores e perfis. In C. S. Hutz (Ed.), Avanços e polêmicas em avaliação psicológica. São Paulo, SP: Casa do Psicólogo.

Villemor-Amaral, A. E. de, \& Pasqualini-Casado, L. (2006). A cientificidade das técnicas projetivas em debate. Psico-USF, 11(2), 185-193. doi: http://doi.org/10.1590/S141382712006000200007

Wartegg, E. (1987). Teste de Wartegg. Diagnóstico de Camadas - WZT. Livros I e II (E. S. von Pflichenfest \& G. M. R. Welter, Trans.). São Paulo, SP: Casa do Psicólogo.

Weiner, I. B. (2000). Princípios da Interpretação do Rorschach (M. C. de V. Moraes, Trans.). São Paulo, SP: Casa do Psicólogo.

Werlang, B. S. G. (2002). TAT, conforme o modelo de Bellak. In J. A. Cunha (Ed.), Psicodiagnóstico-V (pp. 409-415). Porto Alegre, RS: Artmed.

Werlang, B. S. G., \& Cunha, J. A. (1993). Avaliação da personalidade sob enfoque projetivo. In Psicodiagnóstico-R (pp. 123-129). Porto Alegre, RS: Artes Médicas.

(c) BY The Author(s), 2018. Open Access. This article is distributed under the terms of the Creative Commons Attribution 4.0 International License (http://creativecommons.org/licenses/by/4.0/), which permits unrestricted use, distribution, and reproduction in any medium, provided you give appropriate credit to the original author(s) and the source, provide a link to the Creative Commons license, and indicate if changes were made. 